\title{
Governing Jerusalem's Children, Revealing Invisible Inhabitants: The American Colony Aid Association, 1920s-1950s
}

\author{
Julia R. Shatz
}

The Spafford Children's Center is today located between Damascus Gate and Herod's Gate, along the high wall of the Old City in a compound purchased from an Ottoman general over a century ago. The center is a nongovernmental and humanitarian charitable institution that provides a wide range of educational, medical, and cultural services to the underserved Palestinian population of East Jerusalem. The center has served the children of East Jerusalem, in various iterations, over the span of nearly a century. It began as a group of interrelated welfare projects run by the American Colony Aid Association (ACAA), the social service branch of the American colony in Jerusalem. In the late 1920s, the ACAA established a baby home, an infant welfare center and a community playground, to address the needs of local children. The organization transitioned the baby home into a full-fledged children's hospital in the late 1930s. It served families from all over the West Bank after 1948 and transformed into its current iteration as a multiservice social welfare center following the Israeli occupation of East Jerusalem in 1967. Descendants of the original founders continue to sit on the center's board of trustees, which also includes local physicians, businessmen, and community leaders. ${ }^{1}$ Over the long course of its history, the ACAA has been funded through local and international donations from individual, nonprofit, and corporate donors.

The Spafford Children's Center and the ACAA are longstanding Jerusalem institutions that illuminate the way daily life was governed for the city's children. Studying institutions like these offers scholars several means of recovering a more robust history of Jerusalem. The institutions' longevity lends a unique historical perspective through which to view the city. Founded in the 1920s, the center and its institutional predecessors have survived three political eras in East Jerusalem - the British Mandate, Jordanian rule, and the current period

1 Friends of the Spafford Children's Center, Autumn Newsletter 2016, accessed January 19, 2018, http://www.spaffordcenter.org/archives/702.

(C) JULIA R. SHATZ, 2018 | DOI:10.1163/9789004375741_027

This is an open access chapter distributed under the terms of the prevailing CC-BY-NC-ND License at the time of publication. 
of Israeli control. Although they were strongly affected by these political transformations, as nongovernmental institutions their fates were not tied to any single political regime. These types of institutions are important in crafting histories of the city that do not hew to the ruptures of 1948 and 1967. By following the trajectories of institutions that existed in the social realm, we can traverse narrative and archival chasms that otherwise present obstacles to creating a unified history of the city.

Examining nongovernmental organizations engaged in social welfare allows us to tell more complete stories about the operation of daily governance in Jerusalem throughout different historical periods. Thousands of children and families passed through the care of the Spafford Baby Home, clinic, hospital, playground, and children's center, receiving medical attention, educational services and supplemental food aid. On the whole, these families were poor, socially marginalized, and politically underrepresented. By looking at the institutions that served them, these populations become visible in the historical record, in some cases, for the first time. Moreover, many immediate aspects of the everyday life of this population were governed by organizations such as the ACAA. The ACAA and similar organizations formed a network of social governance that may have had more interaction with these populations on a routine basis than the institutions of traditional government did. It is now common to speak of the "NGO-ization" of governance in the post-197os era, during which responsibility for governance and the welfare of the population has shifted from the state to nonstate entities. ${ }^{2}$ For the Global South, scholars have argued that the rise of NGOs and international development aid organizations functions as a type of neoliberal neocolonialism. ${ }^{3}$ In the case of Palestine, specifically, "NGO governance" is most associated with a lack of political statehood and with refugee status, especially following the 1967 War

2 Matthew Hilton, "Politics is Ordinary: Non-Governmental Organizations and Political Participation in Contemporary Britain," Twentieth Century British History 22, no. 2 (2011); Akira Iriye, Global Community: The Role of International Organizations in the Making of the Contemporary World (Berkeley: University of California Press, 2004); Matthew Hilton et al., eds., The Politics of Expertise: How NGOs Shaped Modern Britain (Oxford: Oxford University Press, 2013), 188-217; Thomas Davies, NGOs: A New History of Transnational Civil Society (Oxford: Oxford University Press, 2014).

3 Islah Jad, “The NGO-isation of Arab Women's Movements," IDs Bulletin 35, no. 4 (2004); Julie Hearn, “The 'NGO-isation' of Kenyan Society: USAID \& the Restructuring of Health Care," Review of African Political Economy 25, no. 75 (1998); Kiprono Lang'at, "Deconstructing Neo-Colonialism and Liberalism: Kenya and the NGOs: A Discourse Analysis," International Education Journal 9, no. 2 (2008). 
and Israeli occupation of Gaza and the West Bank. ${ }^{4}$ The story of the ACAA and its role in the operation of social welfare governance, suggests, however, that the relationship of civic voluntary associations to governance and the state has a much longer history than the current literature suggests.

Finally, the history of the ACAA reveals a great deal about the relationship between the local and the international in the everyday governance of Jerusalemites. Scholars have argued that globalization is a process born out of the interactions between global and local culture - a concept Roland Robertson and other sociologists have termed "glocalization..5 Much of the focus of such works has been on the globalizing economy or the globalization of ideas and discourse. As children have become increasingly universalized subjects of governance and care throughout the twentieth century, institutions such as the ACAA have come to represent a different form of "glocalization" the glocalization of humanitarian governance. ${ }^{6}$

This chapter argues that the ACAA and the projects it oversaw were nodes in a larger ad-hoc system of nongovernmental social welfare associations that was at once deeply embedded in the local environs of Jerusalem, and connected to a transnational network of knowledge, personnel, and capital. The essay explores this social welfare network by tracing the development of the ACAA and its work through two distinct eras of its existence. First, it begins with a brief discussion of the history of the American colony and its potential as an archive for new histories of Jerusalem. Second, it examines the establishment of the ACAA during the years of the British Mandate, when its initial social welfare projects emerged within a framework of voluntary associations, colonial governance, and novel global ideas about child welfare. Finally, it looks at the work of the ACAA after 1948, when both the local and international

4 Leila Farsakh, "Undermining Democracy in Palestine: The Politics of International Aid since Oslo," Journal of Palestine Studies 45, no. 4 (2016); Sibille Merz, "'Missionaries of the New Era': Neoliberalism and NGOs in Palestine," Race \& Class 54, no. 1 (2012).

5 Roland Robertson, Globalization: Social Theory and Global Culture (London: Sage, 1992). In the words of Vanessa Ogle, "It has become commonplace to assert that globalization somehow involved the interactions between the global and the local." Vanessa Ogle, "Whose Time Is it? The Pluralization of Time and the Global Condition, 1870s-1940s," The American Historical Review 118, no. 5 (2013): 1379.

6 "Humanitarian governance" is a term employed by Keith Watenpaugh to refer to the creation of protostate entities by subnational groups in the absence of the state. I use the term here to refer to the network of nonstate organizations that indeed provided protostate services in the form of social welfare but did so in concert with the state. Keith Watenpaugh, Bread from Stones: The Middle East and the Making of Modern Humanitarianism (Berkeley: University of California Press, 2015). 
environment had significantly altered in the wake of the Nakba, the emergence of a refugee population, and the rise of international development organizations. The story of the ACAA and other voluntary and nongovernmental organizations involved in social welfare and the care of children offers a new historiographical framework for understanding and narrating a longer history of governance in Jerusalem through the twentieth and twenty-first centuries.

\section{The American Colony: New Archival Potentials}

The origins of the ACAA were in the social welfare projects of the American Colony following the First World War. By the end of the war, the colony had been long established as part of Jerusalem's social service network. The colony was initially founded in 1881 , when the American Spafford family, along with a few friends, emigrated from Chicago to Jerusalem and settled in the Old City as a Christian utopian society committed to communal living and philanthropic service. Unlike the many Christian missionary societies that proliferated throughout the city and its environs at that time, the colony was not interested in proselytization nor was it connected to any larger organization. Colony members instead pursued farming, photography, archaeology, and craft-making. Members worked as nurses and teachers throughout Jerusalem. During and immediately following the war, they ran a soup kitchen to aid Jerusalemites through the locust plague and famine of $1915^{-16}$, and employed poor and widowed women in a dress-making and handicrafts workroom.

In the view of the colony members themselves, their institution and its social works stood in contrast to the similar endeavors of other foreign religious bodies in Palestine. The memoirs of Bertha Spafford Vester, the daughter of the original founders of the colony and its leader through much of the twentieth century, emphasized the distinction between the colony and the Protestant missions that worked in the area. She wrote that other missions were suspicious of the colony because it did not evangelize and operated differently than traditional missionaries. She attributed the missionaries' resentment to the colony members' particular successes in their social welfare work. ${ }^{7}$

While identified as "the Americans" by local missionary groups, the American Colony members did not see themselves as an outpost for American

7 Bertha Spafford Vester, Our Jerusalem: An American Family in the Holy City, 1881-1949 (Jerusalem: Ariel Publishing, 1950), 121. 
interests. ${ }^{8}$ When the United States entered the First World War, the majority of American citizens evacuated Jerusalem. Vester, however, stayed and met with Jamal Pasha to offer her nursing services for wounded Ottoman soldiers. ${ }^{9}$ He permitted the colony to continue its work uninterrupted, and the colony members remained in Jerusalem for the duration of the war. The Ottoman authorities gave the colony purview over one of their military hospitals and enlisted its photography department to document the war and locust plague. ${ }^{10}$

Although the members of the colony thought of their institution as independent and locally embedded, it was deeply intertwined with foreign political authorities and dependent on a transnational financial network. Vester remembered helping the American consul in Palestine, Dr. Otis Allan Glazebrook, to sort and secure British property in Palestine as the Americans took over responsibility for the British consulate at the war's outbreak; Vester and her husband personally housed British and French valuables and title deeds until the end of the war." The colony was also well connected in the United States. When they lacked funds to continue their workroom and soup kitchen during the locust plague, Vester appealed to the Michigan lumber industry titan Edward F. Loud who loaned the colony $\$ 5,000$, and collected additional donations to keep the soup kitchen open. ${ }^{12}$ With the arrival of British forces in Jerusalem in 1917, and the subsequent inauguration of the British Mandate government, the colony became more deeply intertwined with the administrative authorities, politically, socially, and personally.

The American Colony is a well-known entity in Jerusalem as a historical site and hotel, but it also recently joined a growing network of East Jerusalem archives. In 2014, the American Colony Hotel opened its private archive to researchers, following several years of professional cataloguing and organizing. The archive in East Jerusalem complements an additional collection of materials that the colony gave to the Library of Congress in $2005 \cdot{ }^{13}$ The

8 This may have also been due to the fact that while the founding group of the colony consisted solely of Americans, a large Swedish contingent joined the colony in 1896 .

9 Vester, Our Jerusalem, 260.

10 The records of the American Colony Photography Department can be accessed at both the American Colony Archive in East Jerusalem and through the Library of Congress, in the Matson (G. Eric and Edith) Photograph Collection, accessed January 19, 2018, http:// www.loc.gov/pictures/collection/matpc/colony.html.

11 Vester, Our Jerusalem, 248-49.

12 Ibid., 256.

13 Library of Congress, American Colony in Jerusalem, https://www.loc.gov/collections/ american-colony-in-jerusalem/. 
materials in the East Jerusalem archive contain a wide range of items including family artifacts and papers, records of the ACCA, correspondence with financial backers in the United States, and the works of the photography department. Given the colony's longevity in Jerusalem through several political eras and its work in the social sector, the archive offers a unique lens into daily life in the city. It is from these archives that the story of the ACAA, its work, and the lives of the people it cared for can be thoroughly told.

\section{The Mandate Years: A New Network of Welfare}

The ACAA emerged in the late 1920s, as the central organization that oversaw three interrelated social welfare projects of the American colony - the Anna Spafford Baby Home, an infant/child welfare center, and a community playground. Its stated mission was to "further goodwill among all people and to help the less fortunate help themselves"14 through community health and education interventions. The three primary ACAA projects developed out of each other. By the mid-1930s, they had formed a robust social welfare network that aimed to address the physical, social, and moral needs of children of all ages. The first project was the baby home, which led to the idea of establishing a child welfare center that could provide outpatient services and a community playground that would serve as a communal space for all the youth of Jerusalem.

Like the American Colony itself, the origin of the baby home is shrouded in a kind of mythology, which is repeated in Vester's memoir, in all fundraising speeches made on behalf of the ACAA, and in the Spafford Children's Center's contemporary materials. The story goes that on Christmas Eve 1925, Vester encountered a Bedouin man traveling with his sick wife and newborn son. They had journeyed to Jerusalem only to find the hospital closed on account of Christmas. Vester helped the woman gain admission to the hospital, but she died in the morning. The man begged Vester to take in his son, which she did. Soon after, Vester was asked to take in more orphaned babies and the baby home ${ }^{15}$ was born. ${ }^{16}$

\footnotetext{
14 American Colony Aid Association (ACAA), Annual Report of the American Colony Aid Association for the Year 1927-1928, 1.

15 Named so after Vester's mother.

16 Vester, Our Jerusalem, 328.
} 
The origin story of the baby home, with its sense of miraculous coincidence and overt Christian allusions, was certainly a compelling tale to sell the project to potential funders. It also, however, obscured the larger context in which the baby home and the ACAA's broader work of infant and child health care arose. The baby home did not emerge sui generis or simply from the good will and generosity of Vester and other members of the colony. In the 1920s, the baby home and the ACAA's related child welfare projects were pieces of a multi-institutional network of infant clinics and centers in Jerusalem that had emerged out of local, colonial, and global movements for child health care.

When the ACAA began its infant welfare projects, infant mortality and children's health were issues of great concern to doctors, government officials, and social reformers in Jerusalem and throughout Palestine. The war had exacerbated the effects of poverty and deprivation experienced by segments of the Palestinian population, particularly in urban areas. When the occupying British military administration introduced mandatory birth registration in 1918, the newly formed Department of Health was able to officially establish rates of infant mortality in Palestinian cities and towns. In 1920-21, the first year that the department recorded such statistics, the infant mortality rate in Palestine - defined as deaths of children under the age of one year ranged between 123.3 per 1,00o live births in the villages and 209.6 per 1,00o live births in the towns. ${ }^{17}$ The large discrepancy between the urban and rural areas reflected broader inequalities in public health. The impacts of war and poverty were felt more acutely in cities and towns at first, where dilapidated infrastructure and poor sanitation exacerbated the spread of epidemics and infectious diseases. Towns and cities were more likely to suffer from incomplete or defective water systems, which increased rates of infection. Jerusalem, which had a limited piped water system and ample cistern water supply, had comparatively lower infant mortality rates than other urban areas..$^{18}$

The concerns about infant (and maternal) mortality, combined with emerging globalized scientific knowledge about pregnancy, childbirth, and infant care, resulted in the establishment of several postnatal and child welfare clinics throughout Palestine. Voluntary associations of various stripes were the initial impetus behind the founding of many of the clinics, although the Department

17 "Report on the Palestine Administration, July, 1920-December, 1921," in Palestine and Transjordan Administration Reports, vol. 1, 1918-1924 (Farnham Common: Archive Editions, 1995), 266.

18 Ibid. For a robust account of the "hydro-history" of Jerusalem, see Vincent Lemire, La soif de Jérusalem: essai d'hydrohistoire, 1840-1948 (Paris: Publications de la Sorbonne, 2010). 
of Health came to operate half of them by the end of the Mandate period. ${ }^{19}$ Infant welfare centers employed nurses to oversee the clinics' primary work weighing newborns, conducting preventative medical exams for children, treating childhood eye diseases, and instructing mothers in the best feeding and infant care practices of the day. During the Mandate period, these clinics were the only site of interaction with a public health system for many of their patients. The Department of Health did little in the way of direct service work, preferring to contract those duties to voluntary associations when possible. ${ }^{20}$ And while the government mandated birth registration, it was these clinics that kept the primary records on the health of poor populations in a given locality.

The work of all three sites sought to address the physical, social, and moral development of the children and families they served. The ideals of modern medical care and public health that undergirded these projects could not be extricated from colonial ${ }^{21}$ notions of social development and progress. The workers at the baby home, which was intended to care for orphaned and destitute infants, offered courses in "mothercraft" to the poor women of Jerusalem and its surrounding villages. In addition to providing preventative and medical care to infants, the child welfare station also offered instruction to poor mothers in proper hygiene, nutritious cooking, and sewing.

The goal of the mothercraft classes was to instruct the poor women of Jerusalem in the methods of "scientific childrearing." Scientific childrearing was both a global epistemological movement of the early twentieth century, and a contemporary framework for child care in that period. Quite simply, the discourse of scientific childrearing argued that caring for children was a science like any other. It held that there were universal principles about childrearing

19 By 1939, the Department of Health recorded over eighty infant welfare clinics in Palestine. Government of Palestine, Department of Health Annual Report for the Year 1939.

20 It was the official policy of the Department of Health to rely completely on voluntary associations for the direct service work, freeing the department to focus on broad public health issues as well as the care of British colonial officials. In reality, the financial insolvency of many such associations following World War I led the department to take a more active role in direct medical work than initially anticipated.

21 I used "colonial" here not to refer to the political relationship between the British government and the population of Palestine, but as a framework for understanding the unequal relationships of power between welfare organizations such as the ACAA and those whom they served. Movements for child welfare both intended to colonize the practices and knowledge of poor communities and were used by both colonial states and their nonstate collaborators to intervene in the family, social, and political lives colonized populations. 
and its authorities were academics and professionals. ${ }^{22}$ In this context, women had to be taught how to be mothers. Social reformers of all affiliations across Jerusalem embraced this framework. The famous Palestinian physician, Tawfiq Canaan, wrote an article decrying Palestinian mothers' ignorance and reliance on superstition as the root causes of infant mortality and disease. ${ }^{23}$ Scientific childrearing and the assumption of maternal ignorance likewise informed the work of the ACAA, whose annual report of 1930 began thus:

Mothercraft is a word that seems to have been especially coined for the need of this country. The philosophy here is "Allah makes mothers, nature takes care of them, and if anything goes wrong, Allah willed it." Mothers must be taken out of this environment and showed another side of life. ${ }^{24}$

The work of the baby home and child welfare station was thus double-sided: on the one hand, the aim was to provide necessary health services and to fill the gaps left by the Department of Health. On the other hand, these institutions took on roles as architects and disseminators of knowledge and mediators of appropriate and healthy social behavior.

The activities of the community playground were likewise rooted in concerns for both the health and social-moral development of Jerusalem's young population. The initial impetus for the playground's construction was healthoriented: the observation that the children in the urban areas of Jerusalem had more significant health problems than children in the countryside. The ACAA assumed this difference resulted from the lack of open spaces in which children could play, which added to the general problems of sanitation in the city. ${ }^{25}$ The playground was also intended, however, as a space for moral development, where children were given the opportunity to "bring their better natures forward" in learning how to work together and get along. ${ }^{26}$ The playground was also conceived as a space to prevent the development of young men's darker

22 Discourses of scientific childrearing proliferated in social reform circles throughout the globe in the late nineteenth and early twentieth centuries, in the United States, Europe, and the Middle East. Following World War I, this discourse, and the academic and professional experts who promoted it, also permeated new international child welfare organizations, such as Save the Children and the League of Nations' Child Welfare Committee.

23 Tawfik Canaan, "The Child in Palestinian Arab Superstition," Journal of the Palestine Oriental Society 7 , no. 4 (1927).

24 ACAA, Annual Report of the American Colony Aid Association for the Year 1929-1930, 12.

25 ACAA, Annual Report of the American Colony Aid Association for the Year 1927-28.

26 ACAA, Annual Report of the American Colony Aid Association for the Year 1929-30, 20. 
natures. The government probation officer brought his charges to use the playground and praised it as an important measure in preventing delinquency. ${ }^{27}$ As with the baby home and the child welfare station, the logic of the playground necessitated trained professionals to oversee it. Like motherhood, playing could not be assumed to be instinctive or inherently productive. As such, it had to be regulated, organized, and supervised according to the best academic knowledge of the moment. The ACAA enlisted teachers and social worker volunteers, as well as the abovementioned probation officer, to organize the activities of the playground to best bring out its potential for social and moral progress. ${ }^{28}$

The baby home, child welfare station and community playground were not alone in serving the poor children of Jerusalem and its surrounding areas. In 1925, the Department of Health opened an infant welfare clinic in Jerusalem, initially serving a few hundred infants and mothers. ${ }^{29}$ Hadassah, the Zionist medical organization, also opened two child welfare stations in Jerusalem in connection with their private hospital in the early 1920s, and, by the end of the decade, had five clinics in operation. The American Colony cooperated with Hadassah and the other voluntary organizations that undertook infant centers in nearby towns and cities. The physician who oversaw the baby home and child welfare clinic, Dr. Helena Kagan, was formerly the head of pediatrics at the Hadassah-Rothschild hospital in Jerusalem, and was the volunteer doctor at Hadassah's first child health clinic. Although the organizations cooperated with each other and often shared knowledge and resources, the infant welfare system in Jerusalem was explicitly uncoordinated, which at times led to conflict. In a report on their infant welfare centers for 1927, a Hadassah committee complained that the colony had not consulted them before opening a clinic in the same neighborhood of the Old City as one of their own. ${ }^{30}$ Since the American colony's clinic duplicated the work that Hadassah was doing in that area, the committee decided to shut down their clinic to concentrate on another sector of the city. ${ }^{31}$

Through the 1930s, thousands of Jerusalem's children passed through ACAA institutions. In its first year in operation, the child welfare station registered only 236 infants, but by the mid-1930s, it averaged around 3,500 infants a

\footnotetext{
27 ACAA, Annual Report of the American Colony Aid Association for the Year 1931-32, 25.

28 ACAA, Annual Report of the American Colony Aid Association for the Year 1929-30, 21.

29 Government of Palestine, Department of Health Annual Report for the Year 1928, 54.

30 Center for Jewish History (сJH), Record Group 2 (Hadassah Medical Organization) $14 / 46 / 2$.

31 Ibid.
} 
year. ${ }^{32}$ The community playground boasted annual attendances ranging from 21,000 to 57,837 children in the peak year of $19355^{33}$ Although all three institutions were located in the Muslim Quarter of the Old City, and thus served a mostly Muslim population, children of all religions and ethnicities used the ACAA's services. That the social welfare sites were multiethnic and multireligious is not to suggest that they were apolitical spaces, or that scholars should project back into them a kind of utopian historical counterfactual. The political climate of the city greatly affected the children's interactions, as in 1929, when the ACAA reported tensions on the community playground due to the Wailing Wall uprising, or during the 1936-39 Great Revolt, when Jewish children stopped using the playground altogether. ${ }^{34}$ The multicommunal character of these spaces, along with the ACAA's cooperation and collaboration with social welfare organizations of different communities, however, challenges the totality of institutional bifurcation and segregation assumed by the dual society model of Mandate Palestine.

The baby home, child welfare station and community playground were governed by the American Colony in conjunction with several Jerusalemite individuals and funded through a transnational network of private and corporate capital. The advisory committees for both sites consisted of women members of the colony. Dr. Kagan was the attending physician at both institutions, working alongside a Palestinian Arab male physician. They were aided by a collection of nurses culled from the colony, nearby missionary outfits and the local population. Each year, as one of several private institutions in Palestine that trained local nurses and midwives, the baby home hosted five or six Palestinian Arab probationer nurses. Elite American, British, and Palestinian women who were engaged in philanthropic and social welfare works in the city volunteered time at the child welfare station. ${ }^{35}$ The community playground was a microcosm of the amalgamation of community organizations that defined social welfare for the Jerusalemite population in the Mandate years. The Supreme Muslim Council requested use of the playground for the children in its orphanages. ${ }^{36}$ Locals from Jerusalem institutions volunteered at the playground: a senior pupil from the Syrian Orphanage taught a carpentry class, members of the American School of Oriental Research volunteered as

ACAA, Annual Report of the American Colony Aid Association for the Year 1927-28.

33 ACAA, Annual Report of the American Colony Aid Association for the Year 1935-1936, 13.

34 ACAA, Annual Report of the American Colony Aid Association for the Year 1929-1930, 20 and ACAA, Annual Report of the American Colony Aid Association for the Year 1936-1937, 31.

35 ACAA, Annual Report of the American Colony Aid Association for the Year 1929-1930, 18.

36 ACAA, Annual Report of the American Colony Aid Association for the Year 1934-1935, 15. 
supervisors, and the Jerusalem Rotary Club took two boys from the playground on a picnic to the Dead Sea. ${ }^{37}$

A mixture of local and foreign capital funded the American Colony's child welfare institutions. The baby home was founded on initial donations from benefactors in the United States, including the wife of John H. Finley, the former head of the Red Cross Commission in Palestine in the years after the war. ${ }^{38}$ Most families could not afford to pay for their children's care in the home, but the ACAA reports noted that many mothers contributed by way of labor. Funds were donated by wives of colonial officials and the wealthy Palestinian community in Jerusalem. Donations of trees and hay were given in kind to the playground by the Department of Agriculture. ${ }^{39}$ Equipment for the playground was likewise donated by the Jerusalem YMCA and by local individuals. Money was also raised for all three sites through craft sales to tourists from the American Colony's handicrafts school.

Additionally, the ACAA had a well-developed financial network of private individuals and corporate donors, primarily in the United States. Their committee, which was headquartered in New York, was sponsored by politicians, academics, and businessmen including the First Lady of New York State, Eleanor Roosevelt. The ACAA sent annual appeals to this network for donations to carry out their work. In the early 1930s, for example, a new wing of the home was constructed thanks to a donation from friends of the American Colony in Indiana. ${ }^{40}$ In 1928 , a women's sewing society in New York donated infant clothing to the baby home. ${ }^{41}$ On one occasion, Empress Menen Asfaw of Ethiopia, who was already engaged in social welfare and child saving projects in Ethiopia, visited the baby home and donated to its upkeep. ${ }^{42}$

The ACAA's projects also benefitted from corporate philanthropy. Beginning in 1929, William Horlick Jr., son of a well-known family of malted milk purveyors and a subscribing member of the ACAA, made annual donations of malted milk to supplement breastfeeding for the patients of the child welfare station and the baby home. ${ }^{43}$ Though the Horlicks Company was founded in Chicago

ACAA, Annual Report of the American Colony Aid Association for the Year 1929-1930, 21; ACAA, Annual Report of the American Colony Aid Association for the Year 1932-1933, 25.

38 ACAA, Annual Report of the American Colony Aid Association for the Year 1927-1928.

39 ACAA, Annual Report of the American Colony Aid Association for the Year 1929-1930, 22.

40 ACAA, Annual Report of the American Colony Aid Association for the Year 1933-1934, 11.

41 ACAA, Annual Report of the American Colony Aid Association for the Year 1927-28.

42 ACAA, Annual Report of the American Colony Aid Association for the Year 1933-1934, 11.

43 ACAA, Annual Report of the American Colony Aid Association for the Year 1931-1932, 19 and ACAA, Annual Report of the American Colony Aid Association for the Year 1937-1938, 11. 
and headquartered in Racine, Wisconsin, by the 1920 it was a multinational corporation with an additional office in London. Corporate philanthropy was neither new nor exceptional in this period, but the involvement of the Horlicks Company in the ACAA's infant welfare programs raises important questions about the role of corporations in transnational social welfare projects. Analyses of colonial public health that focus solely on the apparatus of state bureaucracy tend to omit private capital from the story. In the postwar period, particularly in the era of market deregulation and global capitalism of the 1970s, multinational corporations would take an enlarged part in providing global humanitarian aid. ${ }^{44}$ The Horlicks Company's corporate philanthropy was not equivalent to the capitalist humanitarianism that would characterize later decades. However, its place in the schema of infant welfare provision in Jerusalem suggests that the story of multinational corporations in global social welfare provision has earlier roots to the postwelfare state and NGO era of the 1970s might lead us to believe.

\section{In the Aftermath of 1948: The ACAA between Arabization and Globalization}

Following the political rupture of the 1948-49 war, the devastation of the Nakba and the division of Jerusalem, the ACAA's work resumed amid a novel sociopolitical landscape. Although its social welfare activities mostly mirrored those undertaken during the Mandate years, the demographic circumstances of the population the ACAA served, as well as the local, national, and international institutional landscape in which it worked, had radically altered. Suddenly serving a mixed population of poor Jerusalem residents and newly displaced refugees, the ACAA formed connections with an emerging local Palestinian relief network. At the same time, the ACAA found itself within a new network of international aid organizations.

The ACAA formally reestablished itself in 1952, following several years of tumult in the wake of the 1948 war. Newly reincorporated under the Jordanian government, the ACAA resumed many of its previous activities albeit amidst a changed population. The reconstituted committee of the ACAA itself had

Tehila Sasson offers an analysis of this phenomenon for the postwar era in "Milking the Third World? Humanitarianism, Capitalism, and the Nestlé Boycott," American Historical Review 121, no. 4 (2016). Sasson's article examines the politics of the provision of artificial milk to infants in the Global South in the 1970s - in her case, in the boycott campaign to end bottle-feeding in the Third World. 
changed demographically, with many more Palestinian Arab members than in its prior iteration. ${ }^{45}$ The baby home, which had been used as an ophthalmic hospital by the Order of St. John's of Jerusalem in the intervening years, was renamed the Spafford Children's Hospital and reopened in 1953. The medical staff in charge of the hospital consisted of Dr. Mahmud Dajani and Mary Kahkedjian, a nurse who had previously worked with the ACAA before spending two years in training at the Boston Children's Hospital. The hospital's primary work was in treating endemic and epidemic diseases of Palestine malaria, eye disease (trachoma), typhoid, dysentery and rickets. ${ }^{46}$ While the hospital continued its work from the Mandate period, it also encountered a new patient population - child refugees. In the first year of the hospital's reopening, refugees accounted for over a quarter of the hospital's admissions; in 1955, two years later, they made up a full third of the patients. ${ }^{47}$

The infant welfare center also reopened in 1953, continuing its work of preventative care, medical treatment, and mothercraft instruction. In the first eight months after the reopening, 769 babies were registered at the center, of which 28 percent were refugees. ${ }^{48}$ Many of these children suffered from malnutrition, and the center provided donations of powdered and fresh milk as it had during the Mandate period. The ACAA also established an outpatient clinic to treat Jerusalem's adult population. The outpatient clinic was meant to cover the gaps left by the absence of hospital accommodation in Jerusalem. As a 1955 ACAA report highlighted, prior to the war and the partition of Palestine, Jerusalem hosted seven or eight private hospitals. ${ }^{49}$ Indeed, in 1918, one British medical missionary deemed Jerusalem "a city of hospitals." ${ }^{50}$ The division of Jerusalem, however, left almost all of those hospitals on the Israeli side of the city, thoroughly disrupting the system of public health for the Palestinian population. The only surviving hospital in East Jerusalem at the end of the war, the Augusta Victoria Hospital, was only able to accept accredited refugees in the early $1950{ }^{51}{ }^{51}$ Public health aid and social welfare governance was bifur-

45 All committee members excluding Vester and her daughter were Palestinian Arab men. American Colony Archive (ACA), American Colony Aid Association Minutes (1952), AC-03-57 (1952-65).

46 ACA, American Colony Aid Association Minutes (1953), AC-03-57 (1952-65).

47 ACA, American Colony Aid Association Annual Report for 1955, AC-03-57 (1952-65).

48 The report notes 215 of the newly registered babies were refugees. ACA, American Colony Aid Association Minutes (1953), AC-03-57 (1952-65).

49 ACA, American Colony Aid Association Annual Report for 1955, AC-03-57 (1952-65).

$50 \quad$ Ernest W. G. Masterman, "Jerusalem from a Point of View of Health and Disease," Lancet 191, no. 4930 (1918): 306.

$5^{1} \quad$ ACA, American Colony Aid Association Annual Report for 1955, AC-03-57 (1952-65). 
cated in the aftermath of the war; while refugees often represented the most disadvantaged of the population, there were new institutions created to serve their needs exclusively, and not those of the existing poor communities of the city. The ACAA struggled in these years to simultaneously accommodate the needs of this novel population and maintain a continual aid network for the nonrefugee Jerusalem poor.

The newly reestablished ACAA joined a network of East Jerusalem social welfare organizations. In the wake of the war, several new and preexisting organizations took on the work of caring for the devastated population. In the immediate environment of East Jerusalem, where the American Colony was located, there were three charitable institutions that specifically cared for poor, orphaned, and refugee children. Dar al-Awlad, a boys' hostel for homeless youth, had been founded in 1940, by a group of Palestinian Arab elites in Jerusalem and under the special patronage of Katy Antonius, wife of George Antonius. ${ }^{52}$ Following the war, Antonius reopened the home as an orphanage. Dar al-Tifl was an orphanage and school established in the wake of the Deir Yassin massacre of 1948, as a refuge for the orphans of the village. The orphanage's founder was Hind Husayni, a member of the powerful Jerusalemite family who had been active in social work, political organizing, and the Arab Women's Union in the 1930s and 1940s. ${ }^{53}$ Rawdat al-Zuhur was a home for destitute girls founded in 1952, by Elizabeth Nasir, the director of the social welfare department in Jerusalem. The ACAA worked closely with these charitable organizations by providing free medical examinations and treatments to their charges, creating a network of nongovernmental social welfare governance in the wake of cataclysmic political upheaval.

In the post-1948 environment, the ACAA was also integrated into emerging networks of international and transnational aid. In its prior incarnation, the ACAA relied on individual donations, corporate philanthropy, and a small amount of government support. While the ACAA continued to tap its wide network of individual backers in the United States, it also received funding from international public health, welfare, and development foundations. For example, the ACAA reopened its institutions in 1953, using a \$33,000 grant from the Ford Foundation. ${ }^{54}$ The United Nations Refugee Works Agency (UN RWA), which was newly established to govern the Palestinian refugee population, likewise assisted the ACAA. Starting in the 1970s, the ACAA also began partnerships with

\footnotetext{
$5^{2}$ Israel State Archives (ISA)/RG 2/P 342/18.

53 Chareen Stark, "The Legacy of Hind al-Husseini," Washington Report on Middle East Affairs: Voices of the Nakba (May-June 2008): 19-20.

54 ACA, American Colony Aid Association Minutes (1953), AC-03-57 (1952-65).
} 
international aid and development organizations such as Oxfam and USAID. ${ }^{55}$ The nature of the ACAA's multifocal and transnational financial network remained constant in the postwar period, but on a dramatically changed scale.

The trajectory of the ACAA's funding relationships in the post-1948 era represented a microcosm of the changing landscape of welfare aid and child welfare specifically. In the interwar period, when child welfare was just becoming a topic of international importance, ad-hoc networks of transnational and local charities and voluntary aid associations led the institutionalization of child welfare schemes. Those networks did not disappear in the postwar moment, but they were integrated into increasingly robust international development institutions. In the case of Palestine, specifically, they were also integrated into new mechanisms of international governance, in the form of the United Nations. At the same time, the governance of the daily lives of poor children in Jerusalem continued to be mediated through local organizations, institutions, and personnel. The mechanisms of international aid and development altered the institutional landscape in which child welfare projects occurred, but did not replace the intensely local character of those projects.

\section{Conclusion}

Since the 1920s, the ACCA and its institutional descendant, the Spafford Children's Center, have been parts of a local and transnational web of social welfare intervention aimed at helping Jerusalem's children. That web of nongovernmental organizations has provided health care, educational services, and welfare aid to the residents of Jerusalem, both in concert with and in the absence of the state. Far from acting simply as temporary relief organizations, these institutions and the services they provide became implicated in the permanent governance of Palestinian children and families. The history of institutions such as the ACAA illuminates the operation of governance in Jerusalem and its continuing dependence on voluntary organizations and nonstate actors. Studying such institutions also sheds light on subject populations such as children, the poor, and the socially marginalized, who have been typically erased in the historical record.

The ACAA and other similar institutions formed a network of daily governance in Jerusalem that was simultaneously locally embedded and transnationally connected. These institutions were essential in the proliferation of ideas about public health and child welfare that reached the global stage 
in the mid-twentieth century. Their day-to-day work and manners of operation, however, reveal that such ideas were filtered, transformed, and realized through local institutions, politics, and relationships. By highlighting the particularities of these local institutions, we can tell a history that is both specific to Jerusalem and connected to broader global stories. 